\title{
Resource politics and the impact of Chinese involvement in small-scale mining in Ghana
}

\author{
Gabriel Botchwey and Gordon Crawford
}

Luning and Pijpers (2017) give a valuable analysis of the interplay between politics and geology in forms of cohabitation between international mining companies and small-scale mining operators on large-scale concessions, which reveals much about the ways in which existing power relations are challenged. 'Indepth geopolitics', inclusive of the three-dimensional perspective, is an innovative concept that highlights important components of the dynamics at work from the state to the community level, and shows how these have succeeded in some situations to push back corporate and state dominance in favour of miners from the locality. The case studies of Keegan Resources and Newmont Ghana are very instructive in pointing out the complexities and contextual nature of cohabitation arrangements between large-scale and small-scale mining operators. Factors that influence or even determine the nature of these arrangements include natural, social, political and security concerns. The article draws attention to the role of chiefs, who indeed have almost always played a part in such negotiations, even though this has not been commonly and openly acknowledged. Artisanal miners, both legal and illegal, have also learned to exploit politicians' need for votes in upcoming elections to their advantage, as the article notes. This weakens the resolve of the state to deal with the negative impact of mining, such as environmental destruction, loss of livelihood, and corruption (Crawford and Botchwey 2017).

The cohabitation situation revealed in the work of Luning and Pijpers (2017) is, however, more complicated and perhaps more tenuous than they acknowledge. With reference to the negotiation by Keegan Resources with miners from the locality, one has to bear in mind that cohabitation is being sought at the expense of 'outsiders' from elsewhere within Ghana. The informal agreement, in exchange for Keegan's exclusive access to the gold outcrop that the company is targeting, precludes such 'outsiders' from operating on the Bonte site. However, given that galamsey operators typically move from site to site and seldom settle in any particular location, often travelling hundreds of miles to work in gangs, it is difficult to vouch for claims that galamsey operators are local or 'autochthonous'. In addition, the prohibition of the use of mechanized equipment on the Bonte site may not stand the test of time. Since 2009, with the involvement of Chinese miners in gold mining, which peaked in 2013, small-scale mining in Ghana has become highly mechanized, involving the use

\footnotetext{
Gabriel Botchwey is a lecturer and former head of the Department of Political Science, University of Education, Winneba, Ghana. He is also a member of the Council for the Development of Social Science Research in Africa (CODESRIA). Email: GKABotchwey@uew.edu.gh

Gordon Crawford is Research Professor in Global Development in the Centre for Trust, Peace and Social Relations at Coventry University. He is also Honorary Professor at University of Freiburg, Germany, and Academic Director (Germany) of the Maria Sybilla Merian Institute for Advanced Studies in Africa (MIASA) at the University of Ghana. Email: gordon.crawford@coventry.ac.uk
}

(C) International African Institute 2018 
of excavators, wash plants and other equipment. These, in comparison to manual 'traditional' methods, have increased small-scale gold production nearly sevenfold. This is common knowledge in the small-scale mining community. Artisanal miners agreeing to use the traditional pickaxe, shovel and bowl at the Bonte site may thus be doing so simply as a strategy to gain access to the site. The deployment of mechanized equipment, in our view, is almost certain to happen; it is only a matter of time.

Regarding Newmont and the ways in which it attempts to gain the consent of the local population for its operations, the article notes the important distinction between formal corporate social responsibility (CSR) activities and the 'strategic tolerance' approach of leaving an area to artisanal miners rather than trying to force them off the company's concession, which would risk the collective opposition of miners, landowners and chiefs. This pragmatic approach allows local miners to mine to a depth beyond which it becomes technologically impossible for them to advance since they cannot get past the water table, leaving Newmont to mine at a deeper level. However, one key issue that the article omits is the size of the concessions that international mining companies such as Newmont obtain from the state, only a proportion of which they actually mine, and the dispossession of land that local communities suffer as a direct consequence. While Newmont's pragmatism provides a useful avenue for cohabitation with some local miners, local people's alienation from the land means that farming and other land-use activities are no longer possible, with consequent adverse effects on local livelihoods. Indeed, many local people have had to switch from farming to illicit mining as a livelihood option. Large-scale mining companies typically disregard areas within their concession that they do not consider economically viable to mine, and, in many cases, artisanal miners gain access to these through incessant agitations and running battles with those companies. The latter tolerate the presence of local miners on 'their' concessions only where their operations and reputation are not threatened. Thus, cohabitation arrangements tend to be negotiated settlements between companies and local miners in contexts of conflict over access to gold resources, and are not born out of a desire to support local employment or to promote economic productivity in the localities. Additionally, such 'cohabitation' does not balance out the dispossession of land suffered by rural dwellers.

The role of the state in prioritizing large-scale over small-scale mining also comes into focus here. Much of the legislation on mining privileges large-scale mining, especially foreign companies, over local artisanal mining. The smallscale mining sector has faced decades of financial and technological neglect by the state. This was a key reason why small-scale Ghanaian miners generally welcomed the recent and unprecedented influx of Chinese miners (Hilson et al. 2014), reportedly numbering tens of thousands from 2008 to $2013,{ }^{1}$ who came with capital and know-how about mechanized mining (Crawford and Botchwey 2017). They used their capital to obtain land and equipment and acquired false documents through bribes to local officials, then undertook mechanized mining operations in Ghana, often in collaboration with local artisanal miners. Mechanized mining has led to an intensification of gold production from the

\footnotetext{
${ }^{1}$ South China Mining Post, 7 July 2013.
} 
small-scale sector, which now accounts for a third of all gold production in Ghana, and increased incomes to between US $\$ 4,000$ and US $\$ 6,500$ per week for Ghanaian mining kingpins, with nearly five times as much going to their Chinese counterparts who financed and undertook the mining operations. No taxes were paid on such incomes. Another significant and negative outcome was the wholesale and blatant environmental destruction of water bodies, ${ }^{2}$ forests and farmlands. ${ }^{3}$ While the involvement of all foreign miners is illegal, with small-scale mining restricted to Ghanaian citizens by law, a 'culture of impunity' developed due to the corrupt behaviour of officials, ${ }^{4}$ chiefs, politicians and security personnel, ${ }^{5}$ all of whom turned a blind eye in return for a share in the loot. In addition, some of the Ghanaian mining kingpins have stated that they have financed politicians to help them get into office, with the implication that any attempt to stop illegal mining is already compromised, or politicians would face the consequences at the ballot box in subsequent elections (Abdulai 2017). Currently, the government does appear to be making a serious attempt to rein in illegal mining and address associated environmental destruction: an initial six-month moratorium on all small-scale mining from April 2017 has subsequently been extended on two occasions, with the ban still in place in late July 2018. However, the involvement of many politicians as beneficiaries of illegal mining would suggest that such efforts could again be compromised. This is a question of old-fashioned politics rather than geopolitics.

The Chinese miners in Ghana largely operated outside the concessions of largescale companies, and hence there were hardly any reported instances of confrontations between the two. Contestations have occurred, instead, between local artisanal miners and Chinese small-scale miners, mainly over access to communal mining sites that have been illegally turned over to Chinese miners by some locals, with the connivance of chiefs and other public officials. Issues of cohabitation between large-scale corporations and local artisanal miners highlighted in Luning and Pijpers' original article did not feature in our study of Chinese involvement (Crawford and Botchwey 2017). Even in settings of minimal Chinese involvement, however, the impact of the mechanization and intensification of mining that has generally resulted from such involvement needs to be acknowledged. Although the majority of Chinese miners left the country as a result of the military task force in mid-2013, the mechanization that they brought has irrevocably changed the nature of small-scale mining in Ghana. In the cohabitation arrangements that Luning and Pijpers analyse, they highlight a shift in power relations that privileges local miners, but such shifts may be short-lived. As small-scale operations become increasingly mechanized, any cohabitation arrangements with international mining companies such as

\footnotetext{
${ }^{2}$ See Water Research Institute (2013).

3'Galamsey: government to spend GHC60,000 to reclaim one hectare of degraded land', GhanaWeb, 13 November 2017 <https://www.ghanaweb.com/GhanaHomePage/NewsArchive/ Galamsey-Government-to-spend-GHC60-000-to-reclaim-one-hectare-of-degraded-land599883>, accessed 31 July 2018.

${ }^{4}$ 'Ghanaians acquiring visas for Chinese to engage in galamsey: minister reveals', GhanaWeb, 12 October 2017 < https://mynewsgh.com/ghanaians-acquiring-visas-for-chinese-to-engage-ingalamsey-minister-reveals/>, accessed 31 July 2018.

${ }^{5}$ See Crawford and Botchwey (2016).
} 
Newmont, or even smaller ones such as Keegan Resources, become increasingly unlikely, given that intensified mining would not be tolerated by the companies on what they regard as their land.

\section{References}

Abdulai, A.-G. (2017) 'The galamsey menace in Ghana: a political problem requiring political solutions?' Policy Brief 5. Accra: University of Ghana Business School.

Crawford, G. and G. Botchwey (2016) 'Foreign involvement in small-scale gold mining in Ghana and its impact on "resource fairness" in M. Pichler, C. Staritz, K. Küblböck, C. Plank, W. Raza and F. Ruiz Peyré (eds), Fairness and Justice in Resource Politics. Abingdon: Routledge.

Crawford, G. and G. Botchwey (2017) 'Conflict, collusion and corruption in small-scale gold mining: Chinese miners and the state in Ghana', Commonwealth and Comparative Politics 55 (4): 444-70.

Hilson, G., A. Hilson and E. Adu-Darko (2014) 'Chinese participation in Ghana's informal gold mining economy: drivers, implications and clarifications', Journal of Rural Studies 34: 292-303.

Luning, S. and R. J. Pijpers (2017) 'Governing access to gold in Ghana: in-depth geopolitics on mining concessions', Africa 87 (4): 758-79.

Water Research Institute (2013) Impact of Small-scale Mining on the Water Resources of the Pra River Basin. Accra: Council for Scientific and Industrial Research (CSIR). 